\title{
Records in tuberculosis detection: perception of health professionals
}

Registros na detecção da tuberculose: percepção dos profissionais de saúde

Registros en la detección de la tuberculosis: percepción de los profesionales de salud

\author{
Jéssica Oliveira Tomberg ${ }^{1}(10)$ \\ Lílian Moura de Lima Spagnolo ${ }^{1}$ (B) \\ Natali Basilio Valerão ${ }^{2}$ (B) \\ Martina Dias da Rosa Martins ${ }^{1}(10)$ \\ Roxana Isabel Cardozo Gonzales ${ }^{1}[$ [D
}

${ }^{1}$ Universidade Federal de Pelotas. Pelotas, RS, Brasil.

${ }^{2}$ Universidade Federal do Rio Grande do Sul. Porto Alegre, RS, Brasil.
Corresponding author:

Jéssica Oliveira Tomberg

E-mail: jessicatomberg@hotmail.com

Submitted on $01 / 08 / 2019$.

Accepted on 04/15/2019.

DOI: 10.1590/2177-9465-EAN-2019-0008

\begin{abstract}
Objective: to know the perception of health professionals about the records produced in the detection of symptomatic respiratory symptoms of tuberculosis. Method: a qualitative study carried out in the municipalities of Sapucaia do Sul and Pelotas (Rio Grande do Sul state). Data were collected between January 2013 and March 2014 with 37 health workers through a semi-structured interview and analyzed in light of the Bardin Content Analysis. Results: three categories emerged, one of which pointed out the potentialities of tuberculosis detection records for case follow-up and two verified the obstacles related to inadequate, excessive duplication of information, requiring physical space for storage and loss of data. records. Conclusion and implications for the practice: the professionals recognize the importance of registries in the detection of tuberculosis, but point out obstacles that make it impossible to apply them in daily life. This information can help municipal managers to reassess the instrument by making advances in the operability of registries in the detection of tuberculosis.
\end{abstract}

Keywords: Tuberculosis. Diagnosis. Health Services. Information System.

\section{Resumo}

Objetivo: Conhecer a percepção dos profissionais de saúde acerca dos registros produzidos na detecção dos sintomáticos respiratórios de tuberculose. Método: Estudo de abordagem qualitativa realizado nos municípios de Sapucaia do Sul e Pelotas (estado do Rio Grande do Sul). Os dados foram coletados entre janeiro de 2013 e março de 2014 com 37 trabalhadores de saúde, através de entrevista semiestruturada e analisada à luz da Análise de Conteúdo de Bardin. Resultados: Emergiram três categorias, uma apontando as potencialidades dos registros da detecção da tuberculose para o acompanhamento dos casos e duas verificaram os entraves que se relacionaram com o preenchimento inadequado, excessivo, com duplicação de informações, exigindo espaço físico para armazenamento e extravio dos registros. Conclusão e implicações para a prática: Os profissionais reconhecem a importância dos registros na detecção da tuberculose, porém apontam entraves que impossibilitam a aplicabilidade no cotidiano. Estas informações podem auxiliar os gestores municipais para reavaliarem os instrumentos produzindo avanços quanto a operacionalidade dos registros na detecção da tuberculose.

Palavras-chave: Tuberculose. Diagnóstico. Serviços de Saúde. Sistema de Informação.

\section{Resumen}

Objetivo: conocer la percepción de los profesionales de salud acerca de los registros producidos en la detección de los sintomáticos respiratorios de tuberculosis. Método: estudio de abordaje cualitativo realizado en los municipios de Sapucaia do Sul y Pelotas (estado de Rio Grande do Sul). Los datos fueron recolectados entre enero de 2013 y marzo de 2014 con 37 trabajadores de salud, a través de una entrevista semiestructurada y estos se analizaron a la luz del Análisis de Contenido de Bardin. Resultados: emergieron tres categorías, una señalando las potencialidades de los registros de la detección de la tuberculosis para el seguimiento de los casos y dos comprobaron los obstáculos que se relacionaron con el llenado inadecuado, excesivo, con informaciones duplicadas, exigiendo espacio físico para el almacenamiento y extravío de registros. Conclusión e implicaciones para la práctica: los profesionales reconocen la importancia de los registros en la detección de la tuberculosis, pero apuntan obstáculos que imposibilitan la aplicabilidad en el cotidiano. Estas informaciones pueden auxiliar a los gestores municipales para reevaluar los instrumentos, produciendo avances en cuanto a la operacionalidad de los registros en la detección de la tuberculosis.

Palabras clave: Tuberculosis. Diagnóstico. Servicios de Salud. Sistema de Información. 


\section{INTRODUCTION}

Tuberculosis is an infectious disease considered a public health problem. In 2017, 10 million new cases were reported worldwide. Brazil is among the 30 countries that concentrate $87 \%$ of the world's cases of the disease, with an incidence rate of $44 / 100$ thousand inhabitants in 2017. 'The "End of Tuberculosis" is one of the goals of the Sustainable Development Objectives, supported by the World Health Organization through recommendations for governments to intensify the care and prevention actions centered on the person and integrating other care, health policies and systems, and research and innovation. ${ }^{1-2}$

The early detection is a strategic action to control the disease, which involves a flow of care, which is established from the first contact between the person with respiratory symptoms of tuberculosis and the health service, preferably in primary health care $(\mathrm{PHC}){ }^{2-3}$ This action includes the active search for cases in the community, the reception of people with symptoms of the disease, the clinical research, the request of sputum smear, the sputum sample collection, the delivery of the sample to the laboratory unit responsible for the analysis and the return of the exam result. The agility and effectiveness of this flow of detection are indispensable because tuberculosis is an infectious disease..$^{2-3}$

At this juncture there is the involvement of several health services, which requires the use of instruments that allow the communication between this network, in order to integrate, promote the continuity of actions and coordination of care by PHC. In the Brazilian health system some forms used are standardized, the one that notifies the System of Notification of Injury Information (SINAN), the request for exams, reports, in addition to the reference and counter-referral forms for referrals between the services. ${ }^{2,4-5}$

Moreover, it is used the records of respiratory symptoms and the Registry of Respiratory Symptomatic in the Health Service (LRSR), which allow the tracking and monitoring of the process of tuberculosis detection. The latter is an instrument standardized by the National Tuberculosis Control Program. ${ }^{2}$

However, operational research on the topic of tuberculosis has shown weaknesses in the use of these instruments. ${ }^{6-10}$ Studies developed in municipalities of Rio Grande do $\mathrm{Sul}^{7}$, of Rio Grande do Norte ${ }^{8}$ and in the metropolitan region of Belém/ $/ \mathrm{PA}^{6}$ identified the absence of LRSR in the health services, the non-use of the book by professionals as the main instrument of monitoring, the incompleteness of data, the lack of readability and even the lack of information.

In this sense, it is identified the fundamental role of health professionals in the effective use of these instruments in daily work. Thus, this article intends to contribute to the knowledge by evaluating the perceptions of professionals regarding the records in the tuberculosis detection process, due to the fact that it is a poorly explored perspective in scientific production.
It is recognized that perception is a psychological activity of meaningful interpretation of environmental and behavioral stimuli, in light of this, knowing the perception of the professionals about the records in the detection of tuberculosis favors the reflection on this element of the work process, making it possible to subsidize health teams and municipal managers in the planning of control actions, as well as awareness of the proper use of records. In this sense, the present study aims to know the perception of health professionals about the records produced in the detection of symptomatic respiratory symptoms of tuberculosis.

\section{METHOD}

A qualitative study conducted between 2013 and 2014 in the municipalities of Sapucaia do Sul and Pelotas, located in the state of Rio Grande do Sul. The municipality of Sapucaia do Sul has a population of 130,957 inhabitants ${ }^{11}$, is organized in four health regions, and in the year 2013 reported 120 cases of tuberculosis. ${ }^{12}$ The primary care network responsible for the detection of tuberculosis cases is composed of 28 units of PHC, in the study period (2013), it had a population coverage of $48.3 \%$ through 14 Family Health teams. ${ }^{13}$ The laboratory responsible for the sputum smear exams is a service outsourced by the municipality, allocated in the neighboring city, and the sputum samples are collected by municipal surveillance vehicle.

The municipality of Pelotas has a population of 328,275 inhabitants..$^{12}$ In 2013 it notified 218 cases of the disease. ${ }^{12}$ It has a total of 50 units of PHC, with a population coverage of $42.9 \%$ of Family Health during the study period. ${ }^{13}$ The laboratory responsible for sputum smears is a municipal public service, which receives sputum samples directly from users.

The study included 37 health workers from PHC units, the laboratory responsible for sputum smear analyses and health surveillance. The semi-structured interview was used as a data collection technique, which was collected between January 2013 and March 2014. Nurses, doctors, assistant nurses and other professional categories such as bureaucrats, biomedicalists and biologists from 14 health units were interviewed. The research questions dealt with the professionals' appreciation of the manual records of the data of the care of people with tuberculosis symptoms, focusing on their advantages and disadvantages.

The interviewers were undergraduate and postgraduate students previously oriented on the instrument and technique of data collection. The interview was scheduled and later performed in the professionals' workplace, in an appropriate and private environment for dialogue and recording with the consent of the participants, by signing the Free Informed Consent Form. 
The interviews were analyzed in the software HyperResearch $\circledast$ 2.8.3 version, using the technique of content analysis, thematic modality, which contemplates the phase of pre-analysis, exploration of the material and treatment of the results..$^{14}$ In the first phase was constituted the "corpus" of the study, which corresponded to the 37 interviews, organized according to an analytical framework for grouping them, composed of columns distributed on the left for numerical order from 1 to 37 and on the right the identification codes of the participants with the letter $M$ followed of the number referring to the municipality (1: Pelotas and 2: Sapucaia) plus the number referring to the order of the interview.

In the phase of exploration of the material, the recording units were determined, that is, words, phrases or paragraphs that corresponded to the most relevant parts of the study (meanings of manual recording). After the identification of the registration units, thematic categories were created. Each interview was considered a primary document. The categories were connected to one or more units related to the thematic axis that met the study objective. Subsequently, the interpretations of the reports contained in the category of analysis identified in the study were made through the interviewees' reports.

Health professionals received guidance on the research and its purpose. They were also informed about the right to participate or not in the study, in its stages. All participants accepted to participate in the study by signing the Free Informed Consent Form. The reliability and anonymity of the participants was assured, as recommended by Resolution No. 466 of December 12, 2012 of the National Health Council. ${ }^{15}$ Research protocol was approved by the Research Ethics Committee, according to Opinion No. 310801, of 2013.

\section{RESULTS}

The results are presented in the following categories: Records in the detection of tuberculosis: potentialities in disease control; Volume, space and time: filling of the records in the detection of tuberculosis (un)needed; and Lost Paper: the search for information.

\section{Records in the detection of tuberculosis: potentialities in disease control}

In the interviews, it was identified that the activities of recording the data in the detection of tuberculosis cases were performed manually, in official printed forms and in the medical records, in all the health services of the municipalities under study. In view of this, and when analyzing the sections presented below, it is verified that the manual registers are pointed as instruments that facilitate the control of the information, considering the possibility of its handling during the care of the person with respiratory symptoms of tuberculosis.

The advantage is the access you have. You can look up both in the book [...] and in the patient's medical record $\left(\mathrm{M1}^{21}\right)$.
It's good because in this green book [LRSR] all data is together, if it were for us to be following medical records or seeing with the community agents, it would be very difficult $\left(M 2^{2}\right)$.

The feeling of control of the information that the printed record offers for these professionals provides a set of information about the care and procedures that were performed, as well as documentation of the suspected symptoms of tuberculosis in some period of life. In addition, the interviewees recognize the records as an important tool to carry out the situational diagnosis of the community served, for the planning of actions and the decision making in the active search of the cases.

We can have a greater control [...] being recorded in the medical record is important, because the patient arrives here, then with some other symptom and he can not say that he had tuberculosis, so it makes it easier for us $\left(\mathrm{M} 1^{13}\right)$.

The record makes it easy because we have [people with tuberculosis] in the unit, we can know how many exams we require and look for [active search], when we find it necessary $\left(\mathrm{M} 1^{19}\right)$.

In this sense, the interviewees demonstrate knowledge about the records recommended to document the detection of cases, highlighting that the LRSR and the medical record of the person with symptoms of tuberculosis are complementary instruments, and it is of the utmost importance to be available at the health units in the tuberculosis detection process.

\section{Volume, space and time: filling in the tuberculosis detection records (un)nedded}

Although professionals perceive the benefits of making records in the detection of tuberculosis, they report some difficulties related to operability and inadequacies in filling. The main difficulty voiced by the interviewees was the volume that the record occupies, which requires the availability of physical space for storage.

Accumulate paper, accumulate space! And we have no more room for that! Every available space we use to assist, and today I have a huge space used with file. Today with technology and everything that exists is extremely outdated doing something with paper record $\left(\mathrm{M} 1^{15}\right)$.

In the above speech, it is evident the experience of structural weaknesses in the health units, which already has little physical space for direct attention to users, and needs to be organized for the preparation of documents. It is also important to understand the existence of mismatch in the form of registration used in the services with the availability of current technology. 
Added to these, the time dismissed for bureaucratic activities, of filling in the forms, which sometimes becomes duplicated. The use of computerized records systems is seen as a potential facilitator for the performance of the assistance with more agility, reducing the excess of physical documents and the repetition of records with the same data in different instruments.

The time you take sometimes filling up papers, having to repeat several information, in the BK request [sputum smear] you have to fill in all the patient's data again $\left(\mathrm{M} 2^{16}\right)$.

More and more we have to write, write and sometimes we repeat two or three times the same thing. I find this very exhausting and waste a lot of time [...]. I think it's lot for us [...] you write in the medical record, you write in the manual that [referring to LRSR], to be registered. Then you have to write to send the report [monthly report sent to the Municipal Program for Tuberculosis Control] (M16).

The manual recording method presents fill-in failures, which may compromise the use of these data for the follow-up actions of people with respiratory symptoms of tuberculosis and use for health planning.

\section{[...] important information is easily left blank. $\left(M 1^{16}\right)$.}

[...]the non-registration of the examination request [...], then we do not know how many sputum smears were ordered during the month, or during a certain period $\left(M 1^{11}\right)$.

[...] You do not have all the patient's data. There is no SUS card, no identity, sometimes no full name, so some data is missing, usually it only has the name, date of birth and our records [assistance information]. So there is a lot missing $\left(\mathrm{M}^{3}\right)^{3}$.

It is quite complex to fill out [referring to the SINAN notification form], so you end up with some [professionals] filling in, if he [professional] is on vacation others do not know how to fill out (M24).

In the words of $\mathrm{M} 11^{11}, \mathrm{M} 11,{ }^{6} \mathrm{M} 2^{3}$ and $\mathrm{M} 2^{4}$ it is evident that the data are lost due to lack of completion, and the records are the responsibility of only some professionals, who were trained or who could understand the SINAN notification form. Problems in the readability of filling also appeared as impediments of the printed records, as it is verified in the sections below:

We have a colleague here that has a writing that does not help much, imagine that you write and the person there some time later has to see and do not find [understands]. It has to be a standard system, in the computer you fill in standardized. Everyone understands, it may be by code, but everyone understands $\left(\mathrm{M}^{12}\right)$.

Difficulty also understanding some writings, because as it is not always us who attend, but students, other professionals, and sometimes we want to search a data in the record and do not understand the writing. If it was registered on the computer, it certainly was more reliable data. Safer! $\left(M 1^{17}\right)$.

$\mathrm{M}^{7}$ and $\mathrm{M}^{2}$ also point out the difficulties in analyzing the epidemiological data for the monitoring of the scope of the goals proposed for the identification of symptomatic individuals and the detection of cases in the territory, attributing this difficulty to the organization of the records.

[...] the data, are recorded there [LRSR] together, without a form of separation, because here we have care of individuals that are of the area of coverage and that are not of the area of coverage, then everything is very close together, for us to do this separation has to do manually, seeing all and separating, which are and which are not [from the area of coverage]. So for us to think about goal, if we are reaching the number of respiratory symptomatic who need [to identify] in the year. We have to do this mechanical separation $\left(\mathrm{M2}^{2}\right)$.

[...] can not create a database with manual registration, you can not analyze with such clarity the data that you collect, everything is very lost, there is a risk of loss, it is complicated to collect. And in a computerized database, in a computerized record you already have the possibility to do [...], has a greater control. I think that's it, more security (M17).

In view of the above, it is noticed that there is a discomfort regarding the excess of filled instruments, together with the difficulty of understanding that cause incompleteness of the records. The possibilities listed for the use of computerized systems are configured as suggestions to minimize failures.

\section{Lost paper: the search for information}

During the process of tuberculosis detection, referral of the person with respiratory symptoms is required to perform tests, or the sending of sputum samples to other services (laboratories). In this process of referencing and counter-referencing there are obstacles in the flow of information between services. This is presented in the speech of $\mathrm{M}^{8}$ on the return of the test results to the $\mathrm{PHC}$ professionals who made the request.

[...] lost ... the result goes to another unit because it comes by car, passes through other units, then passes in another unit [...] then it is lost! I do not know where it is [...] $\left(\mathrm{M}^{8}\right)$.

According to $\mathrm{M} 1{ }^{14}$ the control of the detected cases becomes difficult, with the use of the printed records, since there are losses 
of medical records, attributed to the large volume of documents handled daily.

Every day people lose medical records, every day someone who has lost a medical record appears because there are more than 5 thousand families [...] it is very difficult! (M14).

In addition to the medical records, interviewees also refer to the loss of forms and the LRSR itself, within the health unit, and between laboratory and surveillance services.

\section{[...] Paper when you see it got lost in the middle of other things, it's complicated! $\left(\mathrm{M1}^{6}\right)$.}

Is that sometimes we lose a little piece of paper here and there, then they come to look for and lose some things, I mean the lab, right, the Surveillance (M214).

[...] we had to care for the patient and the prints disappeared. So I think one of the disadvantages is the lack of organization of the service itself, because it stays right there in the meeting room and as we are many here it already happened to lose [...] (M124).

We waste a little more time, we locate, we have to be looking for, sometimes we do not have the material [referring to the LRSR] $\left(\mathrm{M2}^{11}\right)$.

It is observed in the speeches of $\mathrm{M} 2^{14}, \mathrm{M} 1^{24}$ and $\mathrm{M} 2^{11}$ the recurrence of loss of records, whether in the forms, medical records or the LRSR, caused during the team work process in the health service, and also in the physical path that these printed records have to make between the different services necessary for the actions of detection of disease.

\section{DISCUSSION}

The records in the detection of tuberculosis begin with the identification of a respiratory symptom, comprising the documentation in the medical record and the LRSR, standardized by the Ministry of Health, which must be present in all health services. In the interviewees' speeches, the records were recognized as necessary in this process, as well as their applicability in the follow-up of cases, health monitoring and planning actions. However, there was a contradiction in what refers to the potentialities and weaknesses implied in the use of these instruments.

It is understood that the quality of actions to detect tuberculosis is influenced by the individual monitoring of respiratory symptoms by health professionals. Such uniqueness in care allows the continuity of assistance, from its identification to the formalization of the diagnosis, implying agility in recognizing the disease and initiating treatment in a timely manner. Thus, health records have the essential information to assist in the coordination of assistance to the respiratory symptom, providing the professional with the necessary assistance to monitor the actions performed, and the planning and organization of individual and collective assistance. . $^{5-10,16-18}$

In the results of this study, the LRSR was pointed out as the adjuvant instrument in care of person with respiratory symptoms of tuberculosis, providing a consolidated data on the assistance performed. Corroborating with the understanding of nurses interviewed in a study carried out in the municipality of Natal, between the years of 2013 and 2014, who considered that the records related to tuberculosis are instruments that allow access to information for all professionals, being important for the identification of the person with respiratory symptoms of tuberculosis, and the effectiveness of the diagnosis of the disease. ${ }^{16}$ This understanding, on the part of nurses, can be justified by the fact that these professionals centralize the filling of the registration instruments. ${ }^{19}$

It should be emphasized that although the files, forms and the LRSR are easy to understand and complete, the fact that only some professionals take responsibility for their management makes it difficult to involve and apprehend their use by other team members, as can be verified in the speech of M2. ${ }^{4}$ The handling and use of the instruments of record, in the actions of detection of tuberculosis, should integrate the professional practice of all members of the health team. However, these need to be accessible and adequately filled to facilitate the proper performance of the duties of the professionals. ${ }^{16}$

In the present study, the interviewed professionals' perception of printed and standardized records, available for use, is that they present weaknesses related to the quality of the filling, in terms of completeness of data and readability. The incompleteness of the tuberculosis notification form was observed in a study carried out in five Brazilian capitals, ${ }^{4}$ as well as in a study carried out in the interior of Rio Grande do Norte, in which the medical records of people with tuberculosis in PHC units were evaluated, and there was a lack of information essential for the follow-up of the assistance related to illegible spelling and incoherence in writing. ${ }^{8}$

It is worth noting that the lack of diligence in filling in the records by some professionals compromises their applicability to the follow-up of the cases, and may be associated with the lack of understanding of their relevance and/or lack of a culture of utilization of these records by local health in planning and monitoring actions. In view of this, it is recognized that for the full use of the records, the municipal management must be involved in actions of permanent education with training to all professionals working in the detection of tuberculosis. The activities should foster the adequate filling, and the use of these data produced in the territory by the health teams in the continuous supervision of the cases followed and in the evaluation of the actions taken in the control of tuberculosis. ${ }^{4-6}$

The duplicity of data was mentioned, it is necessary to fill in several forms to start the tuberculosis detection process. The bureaucratization of information implies not filling in the data 
due to the overload of records, impact on communication and continuity of care between different services. ${ }^{4-6}$

Even when professionals recognize the potentialities in the use of records, the obstacles related to the form of presentation arise, according to the discourses of $\mathrm{M} 1{ }^{7}$ and $\mathrm{M} 2 .^{2}$ The data produced in the printed format can not be used because of its organization and the filling problems already discussed previously. Making it impossible to operationalize valid information that helps in the situational diagnosis of the assisted community. In the speeches of $\mathrm{M} 1^{14}, \mathrm{M} 1^{6}, \mathrm{M} 1^{24}, \mathrm{M} 2^{14}$ and $\mathrm{M} 2^{11}$ it is common to the services the occurrence of loss of records and printed medical records, attributed by $\mathrm{M} 1^{24}$ the low organization of health services.

In this sense, professionals point out that a computerized system would assist both in the completion of records, as in their use, since the data would be standardized, easy to fill and understand, not occupying spaces and allowing data analysis to be performed. It should be noted that information and communication technologies, is still incipient in Brazilian health services, however, there are efforts of the Ministry of Health along with the National Police of Information and Informatics in Health to improve access, quality and security of information through incentives to use these technologies. ${ }^{18}$ The standardization of records allowed by computerization makes it possible to minimiza the fill-in errors, and eliminates duplication of records, in addition, facilitates the generation of consolidated records and the consequent access to information for health planning. ${ }^{5,19-20}$

In Ribeirão Preto, São Paulo, a computerized system for the communication of tuberculosis control actions was implemented. A study carried out in this scenario showed that the implanted system promoted the awareness of the health team, and that the professionals used the records, generated through the system, to evaluate the assistance offered, which allowed the identification of non-notified cases. ${ }^{5}$ Thus, it is important to progress, structurally and functionally, in the consolidation of computerized information systems, at all levels of attention to the person with tuberculosis.

\section{CONCLUSION AND IMPLICATIONS FOR THE PRACTICE}

Therefore, it is concluded that professionals recognize the importance of records produced in the detection of tuberculosis, mainly related to medical records and LRSR, but perceive as excessive, bureaucratic and unusable in everyday practices. However, they point to disadvantages related to the lack of quality of the filling and the recurrence of loss of the records. It should be noted that the use of computerized systems was cited in comparison to the use of manual registration system, with the potential to qualify information regarding completeness, readability, opportunity and organization.

While limitations of the study it is highlighted that this study was developed in two municipalities of Rio Grande do Sul using similar tuberculosis detection records, which may not reflect the reality of other municipalities. It is also added the limitation of scientific productions on the perception of the records. Therefore, it is suggested the development of research in other states and the investigation of the perception of the municipal managers responsible for tuberculosis control actions regarding the information generated by primary care.

It is noteworthy that knowing the perception of professionals regarding the records is relevant, since they have important implications in the recognition of the fragilities of the records for the production of information in the detection of tuberculosis, suggesting to municipal managers to reassess the instruments used in health units, seeking to qualify strategies that allow the feasibility of using the instruments to fulfill their purpose, to monitor people with tuberculosis, in addition to monitoring and planning in health.

\section{REFERENCES}

1. Word Health Organization. Global Tuberculosis Report 2018. Genebra: World Heath Organization [Internet]. 2018 [citado 2018 set 29]. Disponível em: http://apps.who.int/iris/bitstream/hand le/10665/274453/9789241565646-eng.pdf?ua=1

2. Ministério da saúde (BR). Plano nacional pelo fim da tuberculose como problema de Saúde Pública. 1ª ed. Brasília/DF, 2017.

3. Cecilio HPM, Teston EF, Marcon SS. Access to the diagnosis of tuberculosis from the point of view of health professionals. Texto Contexto. [Internet] 2017; [citado $2018 \mathrm{dez}$ 18]; 26(3):e0230014. Disponível em: http://www.scielo.br/scielo.php?pid=S010407072017000300301\&script=sci_arttext\&tIng=en. Doi: http://dx.doi. org/10.1590/0104-07072017000230014

4. Santos NP, Lirio M, Passos LAR, Dias JP, Kritski AL, Castro Filho BG, et al. Completeness of tuberculosis reporting forms in five Brazilian capitals with a high incidence of the disease. J. bras. pneumol. [Internet] 2013; [citado 2018 out 20]; 39(2): 221-5. Disponível em: http://www. scielo.br/scielo.php?pid=S1806-37132013000200221\&script=sci abstract. Doi: http://dx.doi.org/10.1590/S1806-37132013000200014

5. Órfão NH, Crepaldi NY, Brunello MEF, Andrade RLP, Monroe AA, Netto AR, et al. Coordinated care for tuberculosis: data registration and implementation of a computerized system. Ciênc. Saúde Coletiva. [Internet] 2017; [citado $201818 \mathrm{dez}$ ]; 22(6):1969-77. Disponível em: http://www. scielo.br/scielo.php?script=sci_arttext\&pid=S1413-81232017002601969. Doi: http://dx.doi.org/10.1590/1413-81232017226.15352016

6. Santos BMG, Chagas EM, Machado DV, Nogueira LMV, Rodrigues ILA. Desempenho das ações de controle da tuberculose em municípios prioritários. Gestão e Saúde. [Internet] 2015; [citado 2018 dez 15]; 6(2):1477-94. Disponível em: http://periodicos.unb.br/index.php/rgs/ article/view/22481. Doi: http://dx.doi.org/10.18673/gs.v6i2.22481

7. Spagnolo LML, Tomberg JO, Martins MMDR, Antunes LB, Gonzales RIC. Detecção da tuberculose: a estrutura da atenção primária à saúde. Rev Gaúcha Enferm. [Internet] 2018; [citado 2018 dez 18]; 39:e20180157. Disponível em:https://seer.ufrgs.br/RevistaGauchadeEnfermagem/article/ view/87704. doi: https://doi.org/10.1590/1983-1447.2018.20180157.

8. Junior DNS, Silva YR, Nascimento EGC. Acompanhamento de usuários com tuberculose: Análise da qualidade dos registros nos prontuários. Rev Contexto \& Saúde. [Internet] 2017; [citado 2018 nov 21]; 7(32):15-24. Disponível em: https://www.revistas.unijui.edu. br/index.php/contextoesaude/article/view/5890/0. Doi: https://doi. org/10.21527/2176-7114.2017.32.15-24

9. Beraldo AA, Paula ARL, Orfão NH, Silva-Sobrinho RA, Pinto SG, Wysocki AD, et al. Adesão ao tratamento da tuberculose na Atenção Básica: percepção de doentes e profissionais em município de 
grande porte. Esc. Anna Nery [Internet]. 2017 [citado 2018 set 19]; 21(4): e20170075. Disponível em: http://www.scielo.br/scielo. php?script=sci_arttext\&pid=S1414-81452017000400224\&Ing=en. http://dx.doi.org/10.1590/2177-9465-ean-2017-0075.

10. Yassi A, Adu PA, Nophale L, Zungu M. Learning from a cluster randomized controlled trial to improve healthcare workers' acess to prevention and care for tuberculosis and HIV in Free State, South Africa: the pivotal role of information systems. Global Health Action. [Internet] 2015; [citado $2018 \mathrm{dez}$ 15]; 9(1):305-28. Disponível em: https://www.ncbi.nlm.nih.gov/pmc/articles/PMC4920939/. Doi: https:// doi.org/10.3402/gha.v9.30528

11. Instituto Brasileiro de Geografia e Estatística. Banco de dados de cidades: população 2010. [Internet] 2017; [citado 2018 jul 12]. Disponível em: http://cidades.ibge.gov.br/xtras/home.php

12. Ministério da Saúde (BR). Sistema de Informação de Agravos de Notificação. [Internet] 2017; [citado 2018 ago 05].Disponível em: http:// tabnet.datasus.gov.br/cgi/tabcgi.exe?sinannet/cnv/tubercRS.def/.

13. Ministério da Saúde (BR). Secretaria de Assistência à Saúde. Departamento de Atenção Básica (DAB). Teto, credenciamento e implantação das estratégias de Agentes Comunitários de Saúde, Saúde da Família e Saúde Bucal. [Internet] 2017; [citado 2018 set 13]. Disponível em: http://dab.saude.gov.br/portaldab/historico_cobertura_sf.php.

14. Minayo MCS. O desafio do conhecimento: pesquisa qualitativa em saúde. 12 ed. São Paulo: Hucitec; 2010.

15. Brasil. Conselho Nacional de Saúde. Resolução 466/12. Trata de pesquisas em seres humanos e atualiza a resolução 196. Diário Oficial da União. 12 dez. [Internet] 2012; [citado 2018 ago 10]. Disponível em: http://conselho.saude.gov.br/resolucoes/2012/Reso466.pdf

16. Lopes LMG, Vieira NF, Lana FCF. Análise dos atributos da atenção primária à saúde na atenção à tuberculose no Brasil: uma revisão integrativa. Rev de Enferm do Centro Oeste Mineiro. [Internet] 2015 [citado $2018 \mathrm{dez}$ 05]; 5(2):1684-703. Disponível em: http://www. seer.ufsj.edu.br/index.php/recom/article/view/678. Doi: http://dx.doi. org/10.19175/recom.v0i0.678

17. Rêgo CCD, Macêdo SM, Andrade CRB, Maia VF, Pinto JTJM, Pinto ESG Processo de trabalho da enfermeira junto à pessoa com tuberculose na atenção primária à saúde. Rev Baiana de Enfer. [Internet] 2015; [citado 2018 out 28]; 29(3):218-28. Disponível em: https://portalseer.ufba.br/ index.php/enfermagem/article/view/13038/pdf_6. Doi: http://dx.doi. org/10.18471/rbe.v29i3.13038.

18. Ministério da Saúde (BR). Departamento de Monitoramento e Avaliação do SUS. Política Nacional de Informação e Informática em Saúde. [Internet] 2016; [citado 2017 dez 05]; Brasília: Ministério da Saúde. Disponível em: http://bvsms.saude.gov.br/bvs/publicacoes/politica_ nacional_infor_informatica_saude_2016.pdf.

19. Tomberg JO, Gonzales RIC, Spagnolo LML, Vieira DA, Harter J, Herrera JRRV. Uso de registro eletrônico na detecção da tuberculose: potencialidades e dificuldades na visão dos profissionais. Cogitare Enferm. [Internet] 2018; [citado 2018 nov 23]; 3(23):e53918. Disponíve em: https://revistas.ufpr.br/cogitare/article/view/53918/pdf_en. Doi: http://dx.doi.org/10.5380/ce.v23i3.53918

20. Gava M, Ferreira LS, Palhares D, Mota ELA. Incorporation of information technology in Primary Care of SUS in North-eastern Brazil: expectations and experiences. Cien. Saud Colet. [Internet] 2016; [citado 2018 out 12]; 21(3): 891-902. Disponível em: http://www.scielo.br/scielo. php?script=sci_arttext\&pid=S1413-81232016000300891. Doi: http:// dx.doi.org/10.1590/1413-81232015213.01062015 